\title{
PELAKSANAAN PERILAKU SEHAT PADA ANAK USIA DINI DI PAUD PURWOMUKTI DESA BATUR KECAMATAN GETASAN
}

\author{
Apriliana Kuntoro Astuti \\ Program Studi Pendidikan Guru PAUD - FKIP - UKSW \\ aprilianaa@yahoo.com
}

\begin{abstract}
ABSTRAK
Tumbuh berkembangnya anak usia dini yang optimal tergantung dari perilaku sehat yang dilakukan. Perilaku sehat yang diamati dalam penelitian ini adalah perilaku makan dan minum; perilaku terhadap kebersihan diri; perilaku terhadap kebersihan lingkungan; perilaku terhadap sakit dan penyakit; perilaku keseimbangan (olahraga yang rutin, istirahat dan tidur yang cukup). Penelitian ini bertujuan untuk mendeskripsikan perilaku sehat anak usia dini di PAUD Purwomukti, Desa Batur, Kecamatan Getasan, Kab. Semarang sebagai rekomendasi pada lembaga PAUD untuk bisa ditindaklanjuti, karena lembaga PAUD sebagai patner bagi orang tua murid harusnya melakukan edukasi tentang perilaku sehat bagi anak usia dini dan menjadi tempat kedua untuk melakukan pembiasaan perilaku sehat tersebut. Penelitian ini menggunakan penelitian deskriptif dengan metode survei, dilakukan melalui penyebaran angket secara langsung kepada 27 orang tua/wali murid PAUD Purwomukti. Hasil penelitian menunjukkan bahwa perilaku sehat anak usia dini di PAUD Purwomukti belum dilaksanakan dengan baik oleh peserta didik. Hal ini ditunjukan oleh perilaku yang berada dalam kriteria cukup diantaranya perilaku kebersihan lingkungan $58 \%$, perilaku terhadap kebersihan diri 63\% dan perilaku keseimbangan (kebutuhan tidur dan aktifitas) 65\%. Sedang perilaku makan dan minum $75 \%$; perilaku terhadap sakit dan penyakit $82 \%$ berada dalam kriteria baik.
\end{abstract}

Kata Kunci : perilaku, sehat, anak usia dini

\section{PENDAHULUAN}

Empat tahun pertama seorang anak merupakan hal yang sangat penting karena terjadi pembentukan jaringan dan perkembangan yang sangat cepat (Gardner, 2003:52-56). Salah satu di antaranya adalah dalam proses pembentukan otak dan berdampak terhadap tingkat kecerdasan. Otak manusia adalah salah satu modal pertumbuhan yang sangat pesat (Abdoerachman, 2005:388-389). Sehingga bisa dikatakan anak usia dini adalah investasi bangsa, karena mereka adalah generasi penerus bangsa. Kualitas bangsa di masa depan ditentukan kualitas anak-anak usia dini saat ini. Ini berarti dibutuhkan anak usia dini yang sehat dimana mengalami pertumbuhan fisik yang normal dan wajar sesuai dengan standart pertumbuhan fisik anak pada umumnya dan memiliki kemampuan sesuai standar kemampuan anak seusiannya.

Pertumbuhan dan perkembangan merupakan dua hal yang berbeda. Menurut Soetjiningsih (2002:29) pertumbuhan dan perkembangan memerlukan protein dan asam lemak yang seimbang dan diperlukan stimulasi yang tepat dan berkualitas. Pertumbuhan adalah bertambahnya jumlah sel serta jaringan yang ditandai oleh bertambahnya ukuran fisik dan struktur tubuh sebagian atau keseluruhan, bertambah panjang/tinggi atau berat badannya dan bertambah lengkap struktur tubuhnya. Perkembangan artinya bertambahnya fungsi dan kemampuan tubuh yang lebih kompleks dalam kemampuan gerak kasar, gerak halus, bicara dan bahasa serta sosialisasi, dalam kata lain psikososial.

Upaya peningkatan kualitas sumber daya manusia harus dilakukan sejak dari dini secara sistematis dan berkesinambungan. Tumbuh berkembangnya anak usia dini yang optimal tergantung 
tiga pilar layanan, yaitu asupan gizi, layanan kesehatan dan stimulasi psikososial. Sehingga orang tua, pengasuh dan pendidik anak usia dini harus memiliki pengetahuan serta pemahaman tentang layanan kesehatan, gizi, dan stimulasi psikososial supaya dapat memberikan layanan yang tepat dan berkualitas sesuai dengan kebutuhan pertumbuhan dan perkembangan anak usia dini. Pendidikan kesehatan anak usia dini tidak hanya untuk mengubah dan meningkatkan pertumbuhan dan perkembangan tetapi memahami tingkat pertumbuhan dan perkembangan yang normal serta mekanisme memaksimalkan semua potensi anak usia dini.

Kerjasama yang baik antar pendidik dan orang tua sangat dibutuhkan untuk melakukan optimalisasi pertumbuhan dan perkembangan salah satunya dengan melalui perilaku sehat yang dilakukan oleh anak usia dini. Manfaat mengembangkan perilaku sehat sejak dini adalah anak akan memiliki pola hidup sehat di kemudian hari. Artinya anak usia dini yang terbiasa dengan perilaku hidup sehat tidak mudah hilang pada tahapan perkembangan selanjutnya. Selain itu anak usia dini telah memiliki pola hidup sehat, maka mereka akan terbebas dari serangan berbagai macam penyakit yang sering terjadi pada anak usia dini, seperti batuk/pilek, flek atau TBC, diare, demam, campak. infeksi telinga, dan penyakit kulit. Terlindungi dari potensi kecelakaan yang selalu ada di lingkungan sekitar mereka, seperti keracunan, terjatuh, tenggelam, tertusuk benda tajam atau duri. Berbagai kemampuan yang dimiliki anak usia dini akan tergali dan dapat dikembangkan dengan baik, sehingga anak usia dini dapat tumbuh dan berkembang optimal.

Membentuk pola hidup sehat lebih mudah daripada mengubah perilaku hidup sehat. Sekali lagi tugas membentuk perilaku sehat pada anak usia dini bukan menjadi tugas orang tua semata, melainkan juga pihak sekolah. Antara sekolah dan orang tua harus bekerja sama supaya anak usia dini memperoleh pendidikan tentang pola hidup sehat, sehingga dapat menjadi jaminan untuk hari depan tubuh yang sehat. Tentu saja, dibandingkan dengan sekolah, maka orang tua mempunyai peran yang lebih besar dalam membentuk perilaku sehat ini. Karena orang tua adalah pendidik yang pertama dan utama.

Anak usia dini memiliki kemampuan belajar yang sangat cepat. Teori modelling Bandura (Alwisol 2009:292) menyatakan bahwa anak belajar dari bagaimana orang dewasa memperlakukan mereka. Anak usia dini juga belajar dari apa yang mereka lihat, dengar, dan dari pengalaman tentang suatu kejadian. Anak usia dini belajar melalui pengamatan mereka terhadap suatu kegiatan yang dilakukan orang tua atau gurunya. Anak usia dini belajar dari apa yang mereka dengar dari orang tua dan orang-orang dewasa di sekitar lingkungan mereka. Anak usia dini akan meniru kegiatan orang tua sehingga mereka memperoleh pengalaman tentang suatu kegiatan. Jika orang tua membiasakan perilaku sehat sejak dini, maka anak pun akan terbiasa dengan perilaku sehat tersebut. Misalnya, orang tua membiasakan anak untuk membuang sampah pada tempatnya, maka kebiasaan tersebut akan dimiliki anak sampai tahap perkembangan selanjutnya.

Menurut Syahreni (2011:3) perilaku adalah kegiatan yang dilakukan oleh individu (seseorang), baik yang dapat diamati (dilihat) secara langsung maupun tidak langsung. Sehat adalah suatu kondisi atau keadaan yang baik, mencakup fisik, mental dan sosial, jadi bukan hanya terbebas dari penyakit saja. Sehingga perilaku sehat adalah tindakan sesorang atau kegiatan yang dilakukan oleh seseorang, baik langsung maupun tidak langsung, untuk mempertahankan dan meningkatkan kesehatannya serta mencegah resiko penyakit.

Menurut Notoatmodjo (2010:23) perilaku kesehatan (healthy behavior) diartikan sebagai respon seseorang terhadap stimulus atau objek yang berkaitan dengan sehat-sakit, penyakit, dan faktor-faktor yang memengaruhi kesehatan seperti lingkungan, makanan, minuman, dan pelayanan kesehatan. Dengan kata lain, perilaku kesehatan adalah semua aktivitas atau kegiatan seseorang, baik yang dapat diamati (observable) maupun yang tidak dapat diamati (unobservable), yang berkaitan dengan pemeliharaan dan peningkatan kesehatan. Pemeliharaan kesehatan ini mencakup mencegah 
atau melindungi diri dari penyakit dan masalah kesehatan lain, meningkatkan kesehatan, dan mencari penyembuhan apabila sakit atau terkena masalah kesehatan.

Kesehatan menurut Undang Undang Republik Indonesia tentang Kesehatan (Nomor 36 tahun 2009) adalah keadaan sehat, baik secara fisik, mental, spritual maupun sosial yang memungkinkan setiap orang untuk hidup produktif secara sosial dan ekonomis. Selaras dengan UU definisi sehat yang dikemukakan oleh Organisasi Kesehatan Dunia (WHO) menyatakan sehat adalah keadaan sejahtera jasmani, jiwa dan sosial yang sempurna dan bukan hanya keadaan tanpa penyakit. Jadi, sehat secara menyeluruh melibatkan faktor fisik, mental dan sosial.

Berdasarkan dari pengertian di atas disimpulkan bawah perilaku sehat adalah suatu sikap seseorang terhadap sistem pelayanan kesehatan, sakit dan penyakit, makanan dan minuman serta lingkungan, sehingga seseorang harus mendapatkan zat gizi yang sesuai dengan kebutuhannya, melakukan olah raga secara rutin, memiliki waktu tidur atau istirahat yang cukup, melakukan perawatan gigi dan mulut, menjaga kebersihan diri dan lingkungan, supaya terhindar dari berbagai macam kecelakaan.

PAUD Purwomukti yang berlokasi di Desa Batur, Kecamatan Getasan adalah lembaga pendidikan yang berada di pegunungan Merbabu. Di lokasi yang cenderung dingin ini kita akan menemukan peserta didik dan orang tua/wali murid yang memiliki gigi kuning atau muncul karies. Kuku tangan dan kaki yang tidak rapi, panjang serta hitam. Anak-anak berangkat ke sekolah dengan hanya cuci muka, orang tua/wali murid saat mengantar anaknya juga tidak mandi. Kebiasaan peserta didik dan orang tua yang masih selalu diingatkan untuk buang sampah pada tempatnya. Bekal makanan dan minuman yang di bawa ke sekolah merupakan makanan cepat saji seperti mie instan, serta minuman yang mengandung pemanis buatan. Sehingga diperlukan penelitian untuk mengamati lebih lagi bagaimana sebenarnya perilaku sehat anak usia dini di PAUD Purwomukti, supaya hasil penelitian dapat menjadi rekomendasi bagi lembaga untuk mengambil tindakan.

\section{Dimensi Perilaku Sehat}

Dimensi Perilaku kesehatan dibagi menjadi dua (Soekidjo Notoatmojo, 2010: 24), yaitu:

a. Healthy Behavior (Perilaku Sehat) yaitu perilaku orang sehat untuk mencegah penyakit dan meningkatkan kesehatan. Perilaku-perilaku dalam mencegah atau menghindari dari penyakit sakit dan masalah kesehatan yang lain: kecelakaan atau perilaku preventifdan promotif (Tindakan atau kegiatan untuk memelihara dan meningkatkannya kesehatannya). Contoh: Makan dengan gizi seimbang, olahraga/kegiatan fisik secara teratur, tidak mengkonsumsi makanan/minuman yang mengandung zat adiktif, istirahat cukup, rekreasi /mengendalikan stress.

b. Health Seeking Behavior yaitu perilaku orang sakit untuk mendapatkan kesembuhan dan pemulihan kesehatannya. Disebut juga perilaku kuratif dan rehabilitative yang mencakup kegiatan: 1)Mengenali gejala penyakit ,2) Upaya untuk memperoleh kesembuhan dan pemulihan yaitu dengan mengobati sendiri atau mencari pelayanan baik secara tradisional maupun profesional, 3) Patuh terhadap proses penyembuhan dan pemulihan (complientce).

\section{Faktor-Faktor Yang Mempengaruhi Perilaku Sehat}

Menurut Soekidjo Notoatmojo (2010: 25) faktor - faktor yang berpengaruh terhadap perilaku hidup sehat antara lain: a) Faktor makanan dan minuman terdiri dari kebiasaan makan pagi (sarapan), pemilihan jenis asupan makanan, jumlah makanan dan minuman serta kebersihan makanan. b) Faktor perilaku terhadap kebersihan diri sendiri terdiri dari mandi, membersihkan mulut dan gigi, tangan dan kaki serta kebersihan pakaian. c) Faktor perilaku terhadap kebersihan lingkungan yang 
terdiri dari kebersihan kamar, rumah, lingkungan sekolah. d) Faktor perilaku terhadap sakit dan penyakit terdiri dari pemeliharaan kesehatan, pencegahan terhadap penyakit, rencana pengobatan serta pemulihan kesehatan. e) Faktor keseimbangan antara kegiatan istirahat dan olah raga terdiri dari banyaknya waktu istirahat, aktivitas di rumah atau diluar rumah dan olah raga teratur.

Menurut Notoatmojo (1997:122) Beberapa hal yang perlu diajarkan pada anak untuk mengembangkan perilaku sehat, yaitu menjaga kebersihan diri maupun kebersihan lingkungan dan menjauhkan hal-hal yang berbahaya untuk kesehatan. Kebersihan lingkungan adalah kebersihan tempat tinggal, tempat kerja atau bermain, dan sarana umum. Anak dapat diajarkan tentang kebersihan lingkungan ini sejak dini. Kegiatan paling sederhana yang dapat dilakukan anak usia dini adalah meletakkan alas kaki pada tempatnya; menggunakan alas kaki jika hendak keluar rumah; membuang sampah pada tempatnya; meletakkan peralatan makan minum yang kotor pada tempatnya; membersihkan mainan; menutup mulut pada saat batuk dan bersin; menjauhi asap rokok, asap pembakaran sampah, asap kendaraan bermotor; serta buang air besar (BAB) dan buang air kecil (BAK) di WC. Selain itu orang tua dapat melibatkan anak usia dini dalam kegiatan-kegiatan terkait dengan pemeliharaan kebersihan lingkungan seperti membereskan mainan, menyapu rumah, mengepel rumah, menyapu halaman, dan lain-lain.

Kebersihan diri adalah kebersihan anggota tubuh dan pakaian. Adapun kegiatan untuk menjaga kebersihan diri akan diuraikan sebagai berikut, mandi dilakukan minimal dua kali dalam sehari yaitu pada pagi dan sore. Anak dimandikan dengan menggunakan sabun mandi dan air bersih. Keramas, mencuci rambut dengan menggunakan sampho khusus untuk anak secara teratur dilakukan minimal dua hari sekali. Selanjutnya rambut dirapikan dengan menggunakan sisir yang tepat supaya minyak alami yang terdapat pada rambut dapat menyebar ke seluruh bagian rambut. Sehingga rambut dapat terangsang pertumbuhannya serta melancarkan peredaran darah pada rambut dan kulit kepala.

Membersihkan telinga bagian luar dan bagian belakang telinga setiap hari dengan menggunakan waslap atau handuk pada saat mandi. Menghindari membersihkan lubang telinga bagian dalam karena dapat membahayakan. Karena prinsipnya kotoran telinga dapat keluar dengan sendirinya ketika kita mengunyah makanan. Perawatan gigi, dengan menggosok gigi untuk membersihkan dari sisa-sisa makanan yang menempel pada gigi, karena jika tidak dibersihkan dapat menyebabkan gigi rusak sehingga kemampuan anak untuk menguyah makanan akan terganggu. Agar anak terbiasa merawat giginya, gosoklah gigi anak, segera setelah gigi pertamanya tumbuh dan lakukan gosok gigi secara teratur dua kali sehari, pada pagi dan malam sebelum tidur. Selain itu supaya gigi anak sehat, jauhkan anak usia dini dari makanan atau minuman yang terlalu manis dan bersoda, seperti permen, cokelat, dan soft drink (minuman ringan mengandung soda).

Mencuci tangan, karena kuman dan virus dapat bertahan hidup hingga dua jam di atas permukaan kulit, gagang pintu, meja, mainan, dan lain-lain. Sehingga dapat menyebabkan penyakit seperti pilek, batuk, diare, dan demam. Kebersihan kaki dapat dipelihara dengan membiasakan mencuci kaki setelah mengenakan sepatu, atau setiap pulang dari bepergian, ketika hendak naik ke tempat tidur atau saat akan berangkat tidur. Mengganti baju, mengajari anak usia dini mengganti baju yang sudah dipakai saat keluar rumah dan mengganti baju yang sudah dipakai seharian. Meski tampaknya tidak kotor tetapi di situ banyak sekali debu, keringat, dan kotoran yang menempel.

Kebutuhan gizi, memberikan makanan yang benar pada anak usia sekolah harus dilihat dari banyak aspek, seperti ekonomi, sosial, budaya, agama, disamping aspek medik dari anak itu sendiri. Makanan pada anak usia dini harus serasi, selaras dan seimbang. Serasi artinya sesuai dengan tingkat tumbuh kembang anak. Selaras adalah sesuai dengan kondisi ekonomi, sosial budaya serta agama dari keluarga. Sedangkan seimbang artinya nilai gizinya harus sesuai dengan kebutuhan berdasarkan usia dan jenis bahan makanan seperti kabohidrat, protein dan lemak. 
Kebutuhan tidur dan beraktivitas, seiring dengan bertambahnya usia, kebutuhan tidur seseorang anak semakin berkurang. Saat bayi, sebagian besar waktu anak dihabiskan dengan tidur, maka setelah usia tiga tahun, kebanyakan anak susah untuk tidur siang. Adanya perubahan kebutuhan tidur ini dikarenakan anak telah berubah menjadi sosok yang sangat aktif. Hal ini terjadi karena anak sedang mengembangkan seluruh kemampuan yang ada di dalam dirinya, termasuk memuaskan rasa ingin tahunya yang besar.

Berdasarkan faktor-faktor kebersihan lingkungan, kebersihan diri, kebutuhan gizi, dan kebutuhan tidur dan beraktivitas maka dikembangkan indikator untuk membuat angket penelitian perilaku sehat anak usia dini di PAUD Purwomukti, Desa Batur, Kecamatan Getasan seperti pada table 1.

Table 1. Indikator Perilaku Sehat

\begin{tabular}{|c|c|c|}
\hline NO & ASPEK & INDIKATOR \\
\hline \multirow[t]{6}{*}{1} & Kebersihan Lingkungan & a. Membuang sampah \\
\hline & & b. Merapikan mainan \\
\hline & & c. Membantu membereskan piring setelah makan \\
\hline & & $\begin{array}{l}\text { d. Membantu membersihkan lingkungan sekolah dan } \\
\text { rumah }\end{array}$ \\
\hline & & e. Meletakan sepatu/sandal pada tempatnya \\
\hline & & f. Buang air kecil dan besar pada tempatnya \\
\hline \multirow[t]{6}{*}{2} & Kebersihan Diri & a. Mandi dua kali sehari \\
\hline & & b. Mandi menggunakan sabun \\
\hline & & c. Keramas setiap 2 hari sekali \\
\hline & & d. Menggunakan pasta gigi untuk menggosok gigi \\
\hline & & e. Sikat gigi 2 kali sehari \\
\hline & & f. Membersihkan telinga \\
\hline \multirow[t]{6}{*}{3} & Perilaku Makan dan Minum & a. Terbiasa Sarapan pagi \\
\hline & & b. Minum susu setiap hari \\
\hline & & c. Makan 3 kali sehari \\
\hline & & d. Mau makan sayur \\
\hline & & e. Cuci tangan sebelum makan \\
\hline & & f. Mau minum air putih matang \\
\hline \multirow[t]{6}{*}{4} & Perilaku Sakit Penyakit & a. Memotong kuku \\
\hline & & b. Cuci tangan sebelum makan \\
\hline & & c. Cuci kaki dan tangan \\
\hline & & d. Mau minum obat pada saat sedang sakit \\
\hline & & e. Minta diantar ke dokter pada saat tidak enak badan \\
\hline & & f. Mengganti baju \\
\hline \multirow[t]{6}{*}{5} & Perilaku Keseimbangan & a. Saat sekolah anak mengantuk \\
\hline & & b. Bangun pagi sebelum jam 5 pagi \\
\hline & & c. Tidur lebih dari jam 9 \\
\hline & & d. Melakukan aktifitas tidur siang \\
\hline & & e. Berangkat sekolah jalan kaki \\
\hline & & f. Olah raga seminggu sekali \\
\hline
\end{tabular}




\section{METODE PENELITIAN}

Penelitian ini merupakan penelitian deskriptif. Menurut Sanjaya (2013: 66) penelitian deskriptif adalah jenis penelitian yang berhubungan dengan upaya menjawab masalah-masalah yang ada sekarang dan memaparkannya berdasarkan data yang ditemukan. Menurut Sugiyono (2012:29) penelitian deskriptif adalah metode yang digunakan untuk menggambarkan atau menganalisis suatu hasil penelitian tetapi tidak digunakan untuk membuat kesimpulan yang lebih luas. Metode penelitian yang digunakan dalam penelitian ini adalah metode survei, digunakan untuk mengukur gejala yang ada tanpa menyelediki kenapa gejala tersebut ada dan untuk memperoleh gambaran umum tentang karakteristik populasi. Penelitian ini dilakukan di PAUD Purwomukti, Desa Batur, Kecamatan Getasan dengan subyek orang tua/wali murid yang berjumlah 27 orang. Pemilihan sampel menggunakan teknik probability sampling dengan memberikan kesempatan yang sama untuk diambil. Perbedaan karakter yang mungkin ada pada setiap unsur atau elemen populasi bukan merupakan hal yang penting bagi rencana analisisnya. Teknik pengumpulan data menggunakan instrumen penelitian dalam bentuk lembar angket. Aspek-aspek yang dikumpulkan adalah perilaku kebersihan lingkungan, perilaku kebersihan diri, perilaku makan dan minum (kebutuhan gizi), perilaku keseimbangan (kebutuhan tidur dan beraktifitas) dan perilaku tindakan terhadap sakit penyakit. Data yang sudah terkumpul kemudian dianalisis dan diolah dengan menggunakan statistik sederhana yaitu prosentase. Penilaian kriteria perilaku kesehatan dibagi menjadi tiga yaitu Baik (B), Cukup (C) dan Buruk (B).

Table 2. Penilaian Perilaku Kesehatan

\begin{tabular}{lll}
\hline NO & RANGE NILAI & KRITERIA \\
\hline 1. & $68-100 \%$ & Baik \\
2. & $34-67 \%$ & Sedang/Cukup \\
3. & $0-33 \%$ & Buruk \\
\hline
\end{tabular}

\section{HASIL PENELITIAN DAN PEMBAHASAN}

\section{Deskripsi Hasil Penelitian}

Hasil penelitian didapat dari pengisian angket yang dilakukan oleh 27 orang tua/wali murid di PAUD Purwomukti, Desa Batur, Kecamatan Getasan dengan latar belakang pendidikan yang beraneka ragam. Dibantu oleh dua orang guru dari lembaga untuk melakukan pengisian. Sehingga dari pengisian angket didapat hasil yang sudah diolah sebagai berikut:

\section{Table 3. Hasil Penelitian Perilaku Sehat}

\begin{tabular}{|l|l|l|c|c|}
\hline No & Aspek perilaku & \multicolumn{1}{|c|}{ Indikator } & Hasil & Kriteria \\
\hline 1 & Perilaku & a. Membuang sampah & $58 \%$ & Cukup \\
& Kebersihan & b. Merapikan mainan & & \\
& Lingkungan & c. Membantu membereskan piring setelah makan & & \\
& & d. Membantu membersihkan lingkungan sekolah & dan rumah & \\
& & e. Meletakan sepatu/sandal pada tempatnya & & \\
& & f. Buang air kecil dan besar pada tempatnya & & \\
\hline
\end{tabular}




\begin{tabular}{|c|c|c|c|c|}
\hline 2 & $\begin{array}{l}\text { Perilaku } \\
\text { Kebersihkan Diri }\end{array}$ & $\begin{array}{l}\text { a. Mandi dua kali sehari } \\
\text { b. Mandi menggunakan sabun } \\
\text { c. Keramas setiap } 2 \text { hari sekali } \\
\text { d. Menggunakan pasta gigi untuk menggosok gig } \\
\text { e. Sikat gigi } 2 \text { kali sehari } \\
\text { f. Membersihkan telinga }\end{array}$ & $63 \%$ & Cukup \\
\hline 3 & $\begin{array}{l}\text { Perilaku Makan } \\
\text { dan Minum } \\
\text { (kebutuhan gizi) }\end{array}$ & $\begin{array}{l}\text { a. Terbiasa Sarapan pagi } \\
\text { b. Minum susu setiap hari } \\
\text { c. Makan } 3 \text { kali sehari } \\
\text { d. Mau makan sayur } \\
\text { e. Cuci tangan sebelum makan } \\
\text { f. Mau minum air putih matang }\end{array}$ & $75 \%$ & Baik \\
\hline 4 & $\begin{array}{l}\text { Perilaku } \\
\text { Keseimbangan } \\
\text { (Kebutuhan } \\
\text { tidur/istirahat dan } \\
\text { beraktifitas) }\end{array}$ & $\begin{array}{l}\text { a. Memotong kuku } \\
\text { b. Cuci tangan sebelum makan } \\
\text { c. Cuci kaki dan tangan } \\
\text { d. Mau minum obat pada saat sedang sakit } \\
\text { e. Minta diantar ke dokter pada saat tidak enak ba } \\
\text { f. Mengganti baju }\end{array}$ & $65 \%$ & Cukup \\
\hline 5 & $\begin{array}{l}\text { Perilaku } \\
\text { Tindakan } \\
\text { Terhadap Sakit } \\
\text { Penyakit }\end{array}$ & $\begin{array}{l}\text { a. Saat sekolah anak mengantuk } \\
\text { b. Bangun pagi sebelum jam } 5 \text { pagi } \\
\text { c. Tidur lebih dari jam } 9 \\
\text { d. Melakukan aktifitas tidur siang } \\
\text { e. Berangkat sekolah jalan kaki } \\
\text { f. Olah raga seminggu sekali }\end{array}$ & $82 \%$ & Baik \\
\hline
\end{tabular}

Berdasarkan tabel 2 di atas dapat dianalisa bahwa perilaku kebersihan lingkungan, perilaku kebersihan diri, perilaku keseimbangan (kebutuhan tidur/istirahat dan beraktifitas) berada dalam kriteria cukup, sedang perilaku makan dan minum (kebutuhan gizi) dan perilaku tindakan terhadap sakit penyakit berada dalam kriteria baik.

\section{Pembahasan}

Hasil pengolahan data tersebut telah menjadi masukan bagi lembaga PAUD Purwomukti untuk melakukan evaluasi kegiatan atau program yang berkaitan dengan perilaku sehat anak usia dini. Evaluasi yang disarankan dengan melihat perilaku-perilaku sehat yang berada dalam kriteria cukup. Diantaranya adalah perilaku kebersihan lingkungan, perilaku kebersihan diri, perilaku keseimbangan (kebutuhan tidur/istirahat dan beraktifitas).

Menurut Notoatmojo (1997:122) perilaku terhadap kebersihan lingkungan adalah respon seseorang terhadap lingkungan sebagai determinan kesehatan manusia. Manusia selalu hidup dan berada di suatu lingkungan, seperti lingkungan tempat tinggal, tempat belajar, tempat melakukan aktivitas jasmani dan olahraga ataupun tempat melakukan rekreasi. Manusia dapat mengubah, memperbaiki, dan mengembangkan lingkungannya untuk memperoleh manfaat yang sebesar-besarnya dari lingkungan itu. Namun demikian, sering pula terjadi bahwa manusia, baik secara sadar atau tidak karena ketidaktahuan dan kelalaian ataupun alasan alasan tertentu, malah mengotori lingkungan bahkan kadang-kadang juga merusak lingkungan.

Supaya dapat terus mencapai tingkat kesehatan yang baik manusia harus hidup sehat secara teratur. Hidup sehat diperlukan kondisi lingkungan yang bersih dan sehat. Dimanapun manusia akan 
selalu bersama-sama dengan lingkungannya, baik pada waktu belajar, bekerja, makan-minum maupun istirahat manusia tetap bersatu dengan lingkungannya. Oleh karena itu, kondisi lingkungan perlu benar-benar diperhatikan agar tidak merusak kesehatan sebagai upaya pencegahan yang dapat dilakukan mulai sejak dini, baik dari lingkungan keluarga maupun lingkungan sekolah.

PAUD Purwomukti sebagai patner orang tua harus terus melakukan pembinaan perilaku kebersihan lingkungan melalui program parenting sehingga terjadi kesinambungan dalam pembelajaran dan pembiasaan perilaku kebersihan lingkugan anak usia dini. Karena anak melihat, mendengar, dan meniru suatu kegiatan yang terjadi berulang kali dan akan membentuk pola tertentu pada anak sehingga mereka terbiasa melakukan kegiatan tersebut. Orang tua dan pendidik hendaknya terus memberikan contoh-contoh perilaku kebersihan lingkungan pada anak usia dini sehingga mudah ditiru dan diikuti oleh anak. Melakukan dengan cara-cara yang menarik dan menyenangkan, seperti bermain karena dunia anak adalah dunia bermain. Melalui permainan, anak akan merasa senang untuk meniru sehingga mau melakukan perilaku sehat tersebut.

Perilaku kebersihan diri berada dalam kriteria cukup, berarti PAUD Purwomukti harus menghimbau orang tua/wali murid supaya melakukan kegiatan mandi minimal dua kali dalam sehari dengan menggunakan sabun mandi dan air bersih. Keramas, mencuci rambut dengan menggunakan sampho khusus untuk anak secara teratur dilakukan minimal dua hari sekali. Selanjutnya menyisir rambut dengan menggunakan sisir yang tepat. Membersihkan telinga bagian luar dan bagian luar atau belakang telinga. Perawatan gigi, dengan menggosok gigi secara teratur dua kali sehari, pada pagi dan malam sebelum tidur. Serta menjauhkan anak dari makanan/minuman terlalu manis dan bersoda, seperti permen, cokelat, dan soft drink (minuman ringan mengandung soda). Mencuci tangan dan kaki. Mengganti baju yang sudah dipakai seharian.

Perilaku keseimbangan antara kebutuhan tidur/istirahat dan beraktivitas, berada dalam kriteria cukup. PAUD Purwomukti harus memberi pengertian kepada orang tua/wali murid bahwa seiring dengan bertambahnya usia, kebutuhan tidur seseorang anak yang memang semakin berkurang karena anak telah "berubah" menjadi sosok yang sangat aktif sebab anak sedang mengembangkan seluruh kemampuan memuaskan rasa ingin tahunya yang besar. Bagi anak usia dini antara istirahat dan aktifitas harus seimbang.

Perilaku sehat yang lain, yaitu perilaku makan dan minum dan perilaku tindakan terhadap sakit penyakit, berada dalam kriteria baik bukan berarti diabaikan, namun perlu upaya dari pihak sekolah untuk terus mendukung supaya perilaku sehat semakin sempurna. Antara lain yang perlu menjadi perhatian adalah sarapan pagi sebelum berangkat sekolah, minum susu setiap hari. Memberi masukan kepada orang tua/wali murid supaya memperhatikan asupan gizi anak usia dini berupa nasi, sayur dan lauk setiap harinya. Jangan lupa mencuci tangan sebelum makan dan dilanjutkan.Seminggu sekali dilakukan pemotongan kuku dan serta selalu mengingatkan anak untuk membereskan mainan dan membuang sampah pada tempatnya.Perilaku sehat lain yang tidak bisa dikerjakan di lembaga hendaknya dilakukan oleh orang tua di rumah seperti mandi, keramas, menggosok gigi menjelang tidur, minum susu, dan tidur siang.

\section{SIMPULAN DAN SARAN}

\section{Simpulan}

Perilaku sehat anak usia dini di lingkungan lembaga PAUD Purwomukti belum dilaksanakan dengan baik oleh peserta didik. Hal ini ditunjukan oleh perilaku-perilaku yang berada dalam kriteria cukup diantaranya perilaku kebersihan lingkungan 58\%, perilaku terhadap kebersihan diri $63 \%$ dan perilaku keseimbangan (kebutuhan tidur dan aktifitas) 65\%. Sedang perilaku makan dan minum 75\%; perilaku terhadap sakit dan penyakit $82 \%$ berada dalam kriteria baik. Sehingga lembaga PAUD harus 
terus dilakukan pembinaan serta pendampingan supaya perilaku sehat dapat menjadi gaya hidup anak usia dini.

\section{Saran}

Saran yang peneliti sampaikan dalam penelitian ini, adalah perlu adanya kerjasama antara pihak sekolah dan orang tua yang lebih lagi karena membentuk perilaku anak usia dini tidak bisa dilakukan oleh satu pihak saja. Perilaku sehat harus terus dilakukan secara sistematik dan berkesinambungan supaya tercipta generasi penerus bangsa yang berkualitas karena tumbuh berkembangnya anak usia dini yang optimal tergantung dari perilaku sehat yang dilakukan. Program kegiatan yang ada di PAUD Purwomukti juga bisa menjadi referensi bagi lembaga lain jika ditemukan perilaku sehat anak usia dini dalam kondisi buruk.

\section{DAFTAR PUSTAKA}

Abdoerrachman. 2005. Buku Kuliah Kesehatan Anak. Jakarta : Infomedika.

Alwisol. 2009. Psikologi Kepribadian.Malang : UMM Press.

Gardner, Howard. 2003. Kecerdasan Majemuk. (Terjemahan Drs. Alexander Sindoro). Batam Centre: Interaksara.

Jadin, Ahmad. 2012. Perilaku Hidup Sehat pada Siswa Kelas Atas di SDN Gugus Garuda. Skripsi. Universitas Negeri Yogjakarta. Diperoleh dari http://eprints.uny.ac.id/id/eprint/7507

Mukono. 2000. Prinsip Dasar Kesehatan Lingkungan. Airlangga University Press. Surabaya.

Notoatmodjo, S. 2007. Pendidikan dan Perilaku Kesehatan. Cetakan 2 Jakarta : PT.Rineka Cipta.

Notoatmodjo, S. 2010. Ilmu Perilaku Kesehatan. Rineka Cipta. Jakarta.

Sanjaya, Wina. 2013. Penelitian Pendidikan : Jenis, Metode dan Prosedur. Edisi Pertama. Kencana Prenada Media. Jakarta.

Santoso, S dan Ranti, A.L. 2009.Kesehatan dan Gizi. Rineka Cipta. Jakarta.

Soetjiningsih.2002. Tumbuh Kembang Anak dan Remaja. Jakarta: Sagung Seto.

Sugiyono. 2012. Metode Penelitian Pendidikan : Pendekatan Kuantitatif, Kualitatif, dan R\& D. Bandung : Alfabeta.

Syahreni, E. 2011.Mengembangkan Perilaku Sehat Pada Anak Usia 2-4 Tahun. Direktorat Pembinaan Pendidikan Anak Usia Dini Direktorat Jenderal Pendidikan Anak Usia Dini Nonformal dan Informal Kementerian Pendidikan Nasional.

Wulandari, Heny. 2011. Pelaksanaan Pendidikan Kesehatan Perilaku Hidup Bersih dan Sehat (PHBS) pada Anak Usia Dini di TK ABA Tegalsari Yogjakarta. Tesis. Universitas Islam Negeri Sunan Kalijaga. Yogjakarta. Diperoleh dari http://digilib.uin-suka.ac.id/6824/ 1/BAB\%20I,V.pdf

Undang-Undang Republik Indonesia No 36 Tahun 2009. Tentang Kesehatan. 